\title{
Determination of Optimum Irrigation Regime and Water Use Efficiency of Sugar Beet Grown in Pathogen-Infested Soil
}

\author{
G. Piccinni, Texas A\&M University-Agricultural Research and Extension Center, Uvalde, 1619 Garner Field Road, \\ Uvalde 78801-6205; and C. M. Rush, Texas A\&M University, Texas Agricultural Experiment Station, P.O. Drawer \\ 10, Bushland 79012
}

\begin{abstract}
Piccinni, G., and Rush, C. M. 2000. Determination of optimum irrigation regime and water use efficiency of sugar beet grown in pathogen-infested soil. Plant Dis. 84:1067-1072.

A field experiment was conducted to quantify the effects of different irrigation frequencies on sugar beet yield in pathogen-infested soils. Four irrigation regimes (every 2, 3, 4, and 5 weeks) and four inoculation treatments (beet necrotic yellow vein virus [BNYVV], beet soilborne mosaic virus [BSBMV], BNYVV+BSBMV, and a noninoculated control) were arranged in a splitplot design and replicated four times. Irrigation frequency and virus infection affected disease severity and yield. Sugar beets irrigated every 4 weeks had the lowest disease severity, and yield was not significantly different from the every 2 weeks frequency. Sucrose content was higher for beets in the 4-week irrigation treatment compared with the 2- and 3-week frequencies. Beets inoculated with BNYVV had higher disease severity and lower root yield than beets inoculated with BSBMV and BNYVV+BSBMV. A greenhouse experiment was conducted to evaluate the effect of water level on disease severity and water use in sugar beet. Four treatments (BNYVV, BSBMV, BNYVV+BSBMV, and a noninoculated control) and three water levels (pot capacity [PC], 75\% PC, and 50\% PC) were arranged in a split-plot design and replicated five times. Pots of each treatment were weighed every other day to determine evapotranspiration. Evaporation was determined from unplanted pots, and plant transpiration was calculated by the difference. Beets irrigated at $75 \%$ pot capacity showed minimal disease incidence and a root weight comparable to the fully irrigated healthy control. Plants in the BNYVV treatment had a significantly higher disease severity than beets infected by BSBMV or BNYVV+BSBMV. Root weights and plant water use were significantly affected by virus infection. Beets in the BNYVV+BSBMV treatment had a significantly higher root dry weight and water use than beets in the BNYVV treatment, suggesting that BSBMV reduced the impact of disease caused by BNYVV.
\end{abstract}

Water is the most important compound in an active plant and constitutes more than $80 \%$ of the growing tissue. Because it is essential for most plant functions, the amount of water applied during irrigation, the time and method of water application, the quality of the irrigation water, and prevailing micro-meteorological conditions are important in plant health and yield. The amount of water necessary to maintain foliar temperature or relative water content within an unstressed level may exceed 10 $\mathrm{kg} \mathrm{m}^{-2}$ on a sunny day. The inability of a plant root system to supply such demands is one of the principal constraints of plant productivity (1).

Crop plants rarely attain their full genetic potential for yield because of the limitations imposed by the environment. One common environmental limitation is lack of water. About one-third of all potentially arable land suffers from inadequate water supply, and water deficits affect

Corresponding author: G. Piccinni

E-mail: g-piccinni@tamu.edu

Accepted for publication 5 June 2000

Publication no. D-2000-0804-02R

(C) 2000 The American Phytopathological Society every aspect of plant growth. Yield losses due to water deficit exceed those from all other causes combined (11). Unfortunately, while irrigation reduces water stress problems, it often creates a completely new set of problems. Unbalanced irrigation tends to waste water, nutrients, and energy, and to cause soil degradation by waterlogging and salinization. An increase in disease caused by soilborne pathogens can also result $(2,4-6)$.

Irrigation, by definition, creates a more humid environment, thus promoting the development of some diseases (4). Many diseases develop more rapidly in wet soils, especially when irrigation results in patches of excessive wetness (15). Soil saturation is favorable for the germination and spread of some pathogenic fungi and offers a favorable environment for nematodes. In a series of microplot studies, Cappaert et al. (5) compared the effect of different irrigation amounts on the severity of potato early dying. The authors found greater disease severity in plants grown under excessive irrigation than in those grown under moderate or deficit irrigation regimes. Moreover, as inoculum density increased, reductions in tuber yields were greater under excessive irrigation than under moderate or deficit irrigation re- gimes. Similar results were obtained by Campbell and Copeland (3). They determined that the root system of citrus trees growing in soils frequently saturated by irrigation were prone to Phytophthora root rot.

Wet soils may also indirectly increase potato tuber diseases by maintaining high host tissue water potentials. Lund and Kelman (12) found that an increase in tuber water potential from $-0.8 \mathrm{MPa}$ to $-0.67 \mathrm{MPa}$ dramatically increased the susceptibility of tubers to blackleg infection caused by Erwinia carotovora var. atroseptica.

Variation in irrigation frequency and duration may also influence disease progress for some soilborne pathogens. Ristaino et al. (14) reported that furrow irrigation frequency and duration altered development of Phytophthora root rot on tomatoes. Prolonged irrigation of inoculated plots caused an increase in disease severity compared with other treatments. The authors concluded that avoidance of prolonged irrigation early in the season and application of well-timed, less frequent irrigations of shorter duration will lead to an increase in yield.

Two soilborne viruses of sugar beet that occur in the Texas Panhandle, Beet necrotic yellow vein virus (BNYVV) and Beet soilborne mosaic virus (BSBMV), are transmitted by the fungus Polymyxa betae. The incidence and severity of diseases caused by soilborne viruses and fungi can be higher when a precise irrigation schedule is not followed $(4,15,16)$. Fields are often irrigated excessively, based on the assumption that increasing the amount of water applied to the crop increases tonnage. However, this assumption is incorrect when field soils are infested with soilborne pathogens. The goal of this research was to identify the optimum irrigation regime for maximizing yield and minimizing the effects of BNYVV and BSBMV on sugar beets. To achieve this goal, field and greenhouse experiments were conducted with the following objectives: (i) identify the irrigation frequency that minimizes disease severity and leads to high yields when beets are grown in pathogen-infested soils, and (ii) determine the effects of reduced water amount on yield and disease severity of sugar beets grown in the presence of two soilborne viruses. 


\section{MATERIALS AND METHODS}

Field study. Field studies were conducted at the Texas Agricultural Experiment Station in Bushland in 1996 and 1997 beets. Sixteen 12-row level basins were planted on 5 May 1996 and 24 April 1997 with the sugar beet variety TX18 at 22 seeds per meter planting density. Four inoculation treatments-BNYVV, BSBMV, BNYVV+BSBMV, and a noninoculated control-were established in two-row plots $15.24 \mathrm{~m}$ long. The four inoculation treatments occupied the center eight rows of each 12-row basin. At the end of each row and on each side of the level basins, two filler rows were planted in order to minimize border effects. Seeds were inoculated using the method described by Harveson and Rush (8) with the ratio of 1.5 $\mathrm{g}$ of inoculum containing viruliferous cystospori of $P$. betae: $10 \mathrm{~g}$ of seeds: $10 \mathrm{ml}$ of methyl cellulose. Four furrow irrigation treatments, every 2, 3, 4, and 5 weeks, were arranged in a split-plot design and replicated four times. Irrigation treatment was the main plot and inoculation treatment the subplot. Soil moisture was monitored weekly throughout a $1.8-\mathrm{m}$ profile using a 503 hydroprobe moisture depth nuclear gauge manufactured by CPN Corp. (Martinez, CA).

At the end of the growing season, beets from $1.5 \mathrm{~m}$ from each of two rows in each replication were gently pulled from the ground for disease evaluation. Beet roots were evaluated for the presence of rhizomania and root rot-like symptoms and rated on a scale of 0 to 4 , where 0 represented a healthy beet and 4 a small, hairy, on ground not previously cropped to sugar

and stunted or rotted beet root. After assigning a disease rating, roots were bagged and sent to Holly Sugar, Hereford, TX, for determination of weight and sugar content. After hand sampling was completed, the entire plot was mechanically topped and dug, and plot weight was determined.

Data were analyzed by analysis of variance, and Duncan's multiple range test was used to separate significant treatment differences for each dependent variable. Yield and yield components were also correlated to disease rating, and Pearson's correlation coefficients were evaluated for significance.

Greenhouse study. A greenhouse experiment was conducted in four temperature-controlled tanks (9). This study was conducted to complement the field study and allow a more precise measurement of plant water use efficiency. Each tank contained 32 PVC cylindrical pots $0.20 \mathrm{~m}$ wide and $0.39 \mathrm{~m}$ tall. Pots were filled with a 1:1 ratio by weight of fritted clay and pasteurized field soil. Soda lime was used to adjust the $\mathrm{pH}$ of the fritted clay to 7 (18). Ten kilograms of soil mix was used to fill each pot. Water-holding capacity of the soil mix was determined gravimetrically, and $4.3 \mathrm{~kg}$ of water was added to each pot to achieve water-holding capacity. Temperature inside the tanks was maintained at $25^{\circ} \mathrm{C}$ using an air conditioning unit in conjunction with a heating coil connected to a thermostat. Tank and soil temperature were monitored hourly using copper-constantan thermocouples connected to an AM 416 multiplexer and a 21XL Campbell Scientific data-logger (Campbell Scientific, Logan, UT).

Table 1. Analysis of variance (ANOVA) for number of beets, disease rating, root yield, and percent sugar for the 1996 and 1997 field studies

\begin{tabular}{lcccc}
\hline & Number of beets & Disease rating $^{\mathbf{v}}$ & Yield & \% sugar \\
\hline Year $^{\mathrm{w}}$ & $\mathrm{NS}$ & $* *$ & $\mathrm{NS}$ & NS \\
Irrigation $^{\mathrm{y}}$ & $\mathrm{NS}$ & $* * *$ & $* * *$ & $* * *$ \\
Inoculum $^{\mathrm{z}}$ & $\mathrm{NS}$ & $* *$ & $* *$ & $* *$ \\
Irrigation $^{\mathrm{x}} \times$ inoculum & $\mathrm{NS}$ & $\mathrm{NS}$ & $\mathrm{NS}$ & NS \\
Replication & $\mathrm{NS}$ & $\mathrm{NS}$ & $\mathrm{NS}$ & $\mathrm{NS}$ \\
\hline
\end{tabular}

${ }^{\mathrm{v}}$ On a scale of 0 to 4 , where 0 represented a healthy beet and 4 a small, hairy, and stunted or rotted beet.

w 1996 and 1997 growing seasons.

$\mathrm{x} * *, * * *=$ significant differences at $P=0.05$ and 0.01 , respectively. $\mathrm{NS}=$ nonsignificant.

${ }^{\mathrm{y}}$ Basins furrow irrigated every 2, 3, 4, and 5 weeks.

${ }^{\mathrm{z}}$ Noninoculated, BNYVV, BSBMV, and BNYVV+BSBMV.
TX 18 sugar beet seed were coated with dry beet root tissue containing BNYVV- or BSBMV-viruliferous spores of $P$. betae. Prior to inoculation, root tissue was tested by double antibody sandwich enzymelinked immunosorbent assay (DASELISA) for the presence of the virus (10). Ground root tissue was coated onto the seeds using the coating technique previously referenced for the field study. Five seeds per pot were planted, and after seedling establishment, plants were thinned to one per pot. Pots were kept at full waterholding capacity until the first four true leaves were fully developed, then water stress treatments were initiated. Each pot was weighed daily, and the difference in weight from one day to another was recorded in order to calculate plant evapotranspiration and to replenish the water lost from individual pots. Three irrigation treatments, pot capacity (PC), $75 \%$ PC, and $50 \% \mathrm{PC}$, and four seed inoculation treatments-BNYVV, BSBMV, BNYVV+ BSBMV, and noninoculated control-were arranged in a randomized complete block and replicated five times with two pots for each irrigation by inoculation treatment combination.

One month after initiation of water stress treatments, half of the pots were harvested and number of leaves per plant, leaf area, and root and shoot fresh and dry weight were determined. Plant weight was then added to the total pot weight to account for plant growth when measuring water use. Beets were also evaluated for the presence of virus infection by DASELISA (10).

One month after the first harvest, the remaining pots were harvested, the same plant characteristic determined as at the first harvest, and a disease evaluation was made. Beet roots were evaluated for the presence of rhizomania symptoms (stunting, root constriction, and lateral root proliferation) and rated on a scale from 0 to 4 , where 0 represented a healthy beet and 4 a small, hairy, and stunted beet. This experiment was repeated once.

\section{RESULTS}

Field study. There were no significant differences between the 2 years of the study for all dependent variables except disease rating (Table 1). Therefore, data

Table 2. Effect of irrigation treatment on number of beets per meter, yield, percent sugar, disease ratings, and percent soil moisture for the 2-year field studyw

\begin{tabular}{|c|c|c|c|c|c|c|c|}
\hline \multirow[b]{2}{*}{ Irrigation $^{x}$} & \multirow{2}{*}{$\begin{array}{c}\text { Number of } \\
\text { beets } \mathbf{m}^{-1}\end{array}$} & \multirow[b]{2}{*}{ Yield (mg ha-1) } & \multirow[b]{2}{*}{ Sugar $(\%)$} & \multicolumn{2}{|c|}{ Disease rating ${ }^{y}$} & \multicolumn{2}{|c|}{ Soil moisture (\%) } \\
\hline & & & & 1996 & 1997 & 1996 & 1997 \\
\hline 2 weeks & $11.04 \mathrm{a}^{\mathrm{z}}$ & $54.35 \mathrm{~b}$ & $13.04 \mathrm{~b}$ & $0.83 \mathrm{a}$ & $1.16 \mathrm{a}$ & $28.0 \mathrm{a}$ & $28.07 \mathrm{a}$ \\
\hline 3 weeks & $9.91 \mathrm{a}$ & $52.98 \mathrm{~b}$ & $12.86 \mathrm{~b}$ & $1.00 \mathrm{a}$ & $1.26 \mathrm{a}$ & $26.9 \mathrm{~b}$ & $27.27 \mathrm{~b}$ \\
\hline 4 weeks & $11.10 \mathrm{a}$ & $65.47 \mathrm{a}$ & $13.61 \mathrm{a}$ & $0.43 \mathrm{~b}$ & $0.70 \mathrm{~b}$ & $26.7 \mathrm{~b}$ & $26.51 \mathrm{c}$ \\
\hline 5 weeks & $10.43 \mathrm{a}$ & $42.75 \mathrm{c}$ & $13.89 \mathrm{a}$ & $0.54 \mathrm{~b}$ & $0.73 \mathrm{~b}$ & $25.9 \mathrm{c}$ & $26.07 \mathrm{~d}$ \\
\hline
\end{tabular}

w Values represent the mean across inoculation treatments.

${ }^{x}$ Basins furrow irrigated every 2, 3, 4, and 5 weeks.

y On a scale of 0 to 4 , where 0 represented a healthy beet and 4 a small, hairy, and stunted or rotted beet.

${ }^{\mathrm{z}}$ Means followed by the same letter within a column are not significantly different by Duncan's multiple range test $(P=0.05)$. 
were combined and analyzed together for all dependent variables except disease rating. The main effect interaction was not significant for any of the dependent variables. Therefore, data were analyzed by inoculum inclusive of all irrigation treatments or by irrigation inclusive of all inoculum treatments.

Highly significant differences between years were found for disease rating and among irrigation and inoculation treatments within years. Yield and percent sugar showed significant differences among irrigation and inoculum treatments. Details on mean separation for these two variables are shown in Table 2. Beets irrigated every 4 weeks had a significantly higher root yield and percent sucrose than beets in the other three irrigation frequencies. Sugar beets irrigated every 2 or 3 weeks ranked second for root yield and percent sucrose, whereas sugar beets irrigated every 5 weeks had the lowest root yield. Percent sucrose in beets irrigated every 5 weeks was as high as for those irrigated every 4 weeks. Noninoculated beets and beets inoculated with BSBMV had the highest yield, followed by the beets inoculated with BNYVV+BSBMV. Sugar beets inoculated with BNYVV had the lowest yield (Table 3). Percent sucrose showed a similar pattern. The noninoculated beets had the highest percent sucrose, beets inoculated with BSBMV and BNYVV+BSBMV ranked second, and beets inoculated with BNYVV ranked last.

Differences in disease rating among inoculum treatments and for the 2 years of the study are shown in Table 3. Although disease was not severe in either year, pathogen treatment and irrigation affected disease rating. In 1996 and 1997, sugar beets inoculated with BNYVV had a higher disease rating than the other inoculum treatments. No significant differences were found between sugar beets inoculated with BSBMV or BNYVV+BSBMV in 1996, but in 1997 the treatments differed significantly.

Irrigation treatment had a significant effect on disease rating in both years (Table 2). In 1996, as well as in 1997, sugar beets irrigated every 2 or 3 weeks had significantly more disease than those irrigated every 4 or 5 weeks.

Irrigation frequencies had a significant effect on volumetric water content (Table 2). On average, plots irrigated every 2 weeks had $28 \%$ volumetric water content $\left(\theta_{\mathrm{v}}\right)$ throughout 1.82-m soil depth, which was significantly different from plots irrigated every 3,4 , or 5 weeks. Generally, soil moisture was significantly higher at $0.6 \mathrm{~m}(31 \%)$ than at $1.2 \mathrm{~m}$ and deeper, and the first $0.3-\mathrm{m}$ depth had the greatest water content fluctuation.

Correlation and regression analysis showed a significant strong correlation $(r=$ 0.709 and 0.826 in 1996 and 1997, respectively) between disease rating and irriga- tion frequency (Fig. 1). Plots irrigated every 4 weeks had the least disease conducive to the highest yield and percent sucrose (Table 2, Fig. 1).

Greenhouse study. The greenhouse experiment was repeated once, and significant differences in root fresh weight, shoot dry weight, and root dry weight at first harvest were found between the two experiments. These differences were only in terms of greater plant biomass in experiment 2 compared with experiment 1 . However, rankings of all variables by Duncan's mean separation analysis were the same for the two experiments, and differences in biomass were attributed to the time of the year when experiments were conducted. Experiment 1 was harvested in late winter, whereas experiment 2 was harvested in spring. Although ambient and soil temperature were constant for the two experiments, solar radiation was much higher during experiment 2. Regression analysis between treatment and yield for the two experiments gave similar slopes (17), so the two experiments were analyzed together.

Differences were found among irrigation treatments for the shoot dry weight, root fresh weight, and root dry weight (Table 4). The fully irrigated pots had the greatest leaf area, shoot dry weight, root fresh weight, and root dry weight, followed by the treatment at $75 \%$ pot capacity and then $50 \%$ pot capacity (Table 5).

All dependent variables were significantly different among irrigation treatments in the second (final) harvest (Table 4). Root fresh and dry weight, and disease rating were also significantly different among inoculation treatments, and there was a significant irrigation by inoculation treatment interaction. For this reason, data were sorted by inoculation and by irrigation treatment for these last three dependent variables.

Means separation analysis for leaf area, shoot fresh weight, and shoot dry weight showed significant differences among all irrigation treatments. Beets grown at pot capacity had the highest leaf area, shoot fresh weight, and shoot dry weight, while those grown at $50 \%$ pot capacity had the lowest (Table 5).

Root fresh weight was affected by the inoculation treatment showing significantly lower yields in the presence of BNYVV and BSBMV+BNYVV in the pot capacity irrigation treatment. These differences became nonsignificant at the 75 and $50 \%$ irrigation treatments. Root dry weight showed a significant difference only be-

Table 3. Effect of inoculum treatment on number of beets per meter, yield, percent sugar, and disease ratings for the 2-year field studyw

\begin{tabular}{|c|c|c|c|c|c|}
\hline \multirow[b]{2}{*}{ Inoculation $^{y}$} & \multirow{2}{*}{$\begin{array}{l}\text { Number of } \\
\text { beets } \mathbf{m}^{-1}\end{array}$} & \multirow{2}{*}{$\begin{array}{c}\text { Yield } \\
\left(\mathrm{mg} \mathrm{ha}^{-1}\right)\end{array}$} & \multirow[b]{2}{*}{ Sugar (\%) } & \multicolumn{2}{|c|}{ Disease rating $^{x}$} \\
\hline & & & & 1996 & 1997 \\
\hline Control & $11.16 \mathrm{a}^{\mathrm{z}}$ & $54.05 \mathrm{a}$ & $13.71 \mathrm{a}$ & $0.34 \mathrm{c}$ & $0.47 \mathrm{c}$ \\
\hline BNYVV+BSBMV & $10.45 \mathrm{a}$ & $50.91 \mathrm{~b}$ & $13.33 \mathrm{~b}$ & $0.62 \mathrm{~b}$ & $1.47 \mathrm{~b}$ \\
\hline BSBMV & $10.56 \mathrm{a}$ & $53.86 \mathrm{a}$ & $13.36 \mathrm{~b}$ & $0.61 \mathrm{~b}$ & $0.63 \mathrm{c}$ \\
\hline BNYVV & $10.31 \mathrm{a}$ & $43.32 \mathrm{c}$ & $13.01 \mathrm{c}$ & $1.10 \mathrm{a}$ & $2.11 \mathrm{a}$ \\
\hline
\end{tabular}

w Values represent the mean of all irrigation treatments combined.

${ }^{x}$ On a scale of 0 to 4 , where 0 represented a healthy beet and 4 a small, hairy, and stunted or rotted beet.

y Sugar beet seed were either noninoculated or inoculated with Polymyxa betae spores infected with Beet necrotic yellow vein virus (BNYVV), Beet soilborne mosaic virus (BSBMV), or BNYVV+BSBMV.

${ }^{\mathrm{z}}$ Means followed by the same letter within a column are not significantly different by Duncan's multiple range test $(P=0.05)$.

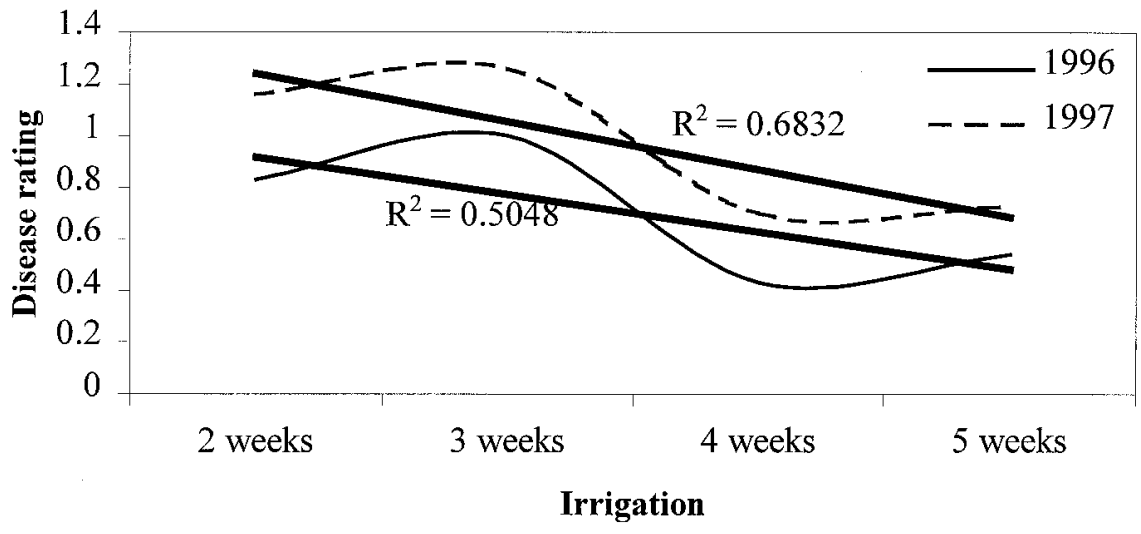

Fig. 1. Relationship between disease ratings across virus inoculation treatments and frequency of irrigation in 1996 and 1997. Sugar beet seed were either noninoculated or inoculated with Polymyxa betae spores infected with Beet necrotic yellow vein virus (BNYVV), Beet soilborne mosaic virus (BSBMV), or BNYVV+BSBMV. Plots were furrow irrigated every 2, 3, 4, or 5 weeks. 
tween the control treatment and BNYVV. Significant differences were found in disease rating among the inoculation treatments at full pot capacity. Beets in the three virus-inoculated treatments had higher disease ratings than the noninoculated control. However, these differences became nonsignificant at 75 and $50 \%$ pot capacity. Furthermore, beets in the noninoculated pots had significantly reduced root fresh weight and root dry weight as irrigation decreased. BSBMV, BSBMV+ BNYVV, and BNYVV treatments showed a significant reduction in root fresh weight and root dry weight between PC and 50\% PC. The 75 and 50\% PC irrigation treatments significantly reduced the disease rating of beets in the BSBMV+BNYVV and BNYVV treatments (Table 6).

BNYVV significantly reduced plant evapotranspiration compared with the BSBMV and BNYVV+BSBMV treatments. As pots were kept at 75 or $50 \%$ of the full pot capacity, differences in plant evapotranspiration were no longer significant among inoculation treatments (Table 7).
Water use efficiency for the four inoculation treatments is graphically represented in Figure 2. The regression slope values represent the water use efficiency. The only significant difference in water use efficiency was found between the control treatment and all other treatments.

\section{DISCUSSION}

Good irrigation management is one of the most important agronomic practices for achieving profitable yields. This is particularly true when irrigation is done in fields where soilborne pathogens are present. BNYVV and BSBMV are soilborne viruses that are widespread throughout many of the major sugar beet growing regions of the United States. Yield losses can be extremely high in the presence of BNYVV, and keeping fields too wet or at field capacity in an attempt to achieve maximum yields is highly conducive to disease spread and high disease severity.

Several studies have been conducted on various crops to determine the effect of different irrigation regimes on develop- ment of diseases caused by soilborne pathogens $(2,4-7,9,14,16)$. One of the objectives of our study was to determine the optimum irrigation frequency for achieving profitable sugar beet yields in the presence of two soilborne pathogens. The results we obtained are in general agreement with other studies in which limited irrigation was used to control diseases caused by soilborne pathogens $(2,4-6,14,16)$.

Cappaert et al. (5) reported a positive correlation between irrigation and symptoms of potato early dying (Verticillium dahliae Kleb.). Plants had earlier and greater disease symptoms with excessive irrigation prior to tuber initiation. We also found a strong relationship between irrigation frequency and disease index. Sugar beets irrigated every 4 weeks had the lowest disease incidence and the highest yield. These results are also in agreement with those obtained by Ristaino et al. (14). In their study, the authors found a significant positive correlation between irrigation frequency and duration with disease development. Prolonged irrigation of inoculated

Table 4. Analysis of variance (ANOVA) for various yield components at harvests 1 and 2 for the greenhouse experiment

\begin{tabular}{|c|c|c|c|c|c|c|c|c|c|c|c|}
\hline & \multicolumn{5}{|c|}{ Harvest 1} & \multicolumn{6}{|c|}{ Harvest 2} \\
\hline & $\begin{array}{c}\text { Shoot fresh } \\
\text { weight }\end{array}$ & $\begin{array}{l}\text { Leaf } \\
\text { area }\end{array}$ & $\begin{array}{c}\text { Shoot dry } \\
\text { weight }\end{array}$ & $\begin{array}{c}\text { Root fresh } \\
\text { weight }\end{array}$ & $\begin{array}{c}\text { Root dry } \\
\text { weight }\end{array}$ & $\begin{array}{c}\text { Shoot fresh } \\
\text { weight }\end{array}$ & $\begin{array}{l}\text { Leaf } \\
\text { area }\end{array}$ & $\begin{array}{c}\text { Shoot dry } \\
\text { weight }\end{array}$ & $\begin{array}{c}\text { Root fresh } \\
\text { weight }\end{array}$ & $\begin{array}{c}\text { Root dry } \\
\text { weight }\end{array}$ & $\begin{array}{c}\text { Disease } \\
\text { rating }\end{array}$ \\
\hline Irrigation $^{\mathrm{x}}$ & $\mathrm{NS}^{\mathrm{y}}$ & $* * *$ & $* * *$ & $* * *$ & $* * *$ & $* * *$ & $* * *$ & **** & $* * *$ & $* * *$ & $* * *$ \\
\hline Inoculum $^{\mathrm{z}}$ & NS & NS & NS & NS & NS & NS & NS & NS & $*$ & $* * *$ & $* * *$ \\
\hline $\begin{array}{c}\text { Irrigation } \times \\
\text { inoculum }\end{array}$ & NS & NS & NS & NS & NS & NS & NS & NS & $* *$ & $* *$ & $* *$ \\
\hline Replication & NS & NS & NS & NS & NS & NS & NS & NS & NS & NS & NS \\
\hline
\end{tabular}

$x$ Pot capacity (PC), 75\% PC, and 50\% PC.

y **, *** $=$ significant differences at $P=0.05$ and 0.01 , respectively. NS $=$ nonsignificant differences.

${ }^{\mathrm{z}}$ Sugar beet seed were either noninoculated or inoculated with Polymyxa betae spores infected with Beet necrotic yellow vein virus (BNYVV), Beet soilborne mosaic virus (BSBMV), or BNYVV+BSBMV.

Table 5. Effect of irrigation treatment on leaf area, shoot dry weight, root fresh and dry weight at harvest 1 , and leaf area, shoot fresh and dry weight at harvest 2 for the greenhouse experiment ${ }^{y}$

\begin{tabular}{|c|c|c|c|c|c|c|c|}
\hline \multirow[b]{2}{*}{ Irrigation } & \multicolumn{4}{|c|}{ Harvest 1} & \multicolumn{3}{|c|}{ Harvest 2} \\
\hline & $\begin{array}{c}\text { Leaf area } \\
\left(\mathrm{cm}^{-2}\right)\end{array}$ & $\begin{array}{l}\text { Shoot dry } \\
\text { weight (g) }\end{array}$ & $\begin{array}{l}\text { Root fresh } \\
\text { weight (g) }\end{array}$ & $\begin{array}{c}\text { Root dry } \\
\text { weight (g) }\end{array}$ & $\begin{array}{c}\text { Leaf area } \\
\left(\mathrm{cm}^{-2}\right)\end{array}$ & $\begin{array}{c}\text { Shoot fresh } \\
\text { weight (g) }\end{array}$ & $\begin{array}{l}\text { Shoot dry } \\
\text { weight (g) }\end{array}$ \\
\hline Pot capacity & $2,863.70 \mathrm{a}^{\mathrm{z}}$ & $25.34 \mathrm{a}$ & $65.92 \mathrm{a}$ & $8.60 \mathrm{a}$ & $3,677.7 \mathrm{a}$ & $441.62 \mathrm{a}$ & $49.02 \mathrm{a}$ \\
\hline $75 \%$ pot capacity & $2,125.14 \mathrm{~b}$ & $19.78 \mathrm{~b}$ & $46.44 \mathrm{~b}$ & $6.74 \mathrm{~b}$ & $2,945.5 \mathrm{~b}$ & $296.79 \mathrm{~b}$ & $37.51 \mathrm{~b}$ \\
\hline $50 \%$ pot capacity & $872.92 \mathrm{c}$ & $13.13 \mathrm{c}$ & $22.20 \mathrm{c}$ & $4.16 \mathrm{c}$ & $1,011.9 \mathrm{c}$ & $165.81 \mathrm{c}$ & $22.26 \mathrm{c}$ \\
\hline
\end{tabular}

y Values represent the mean of all inoculation treatments combined.

${ }^{\mathrm{z}}$ Means followed by the same letter within a column are not significantly different by Duncan's multiple range test $(P=0.05)$.

Table 6. Effect of irrigation and inoculation treatments on root fresh weight, root dry weight, and disease rating at harvest 2 for the greenhouse experiment

\begin{tabular}{|c|c|c|c|c|c|c|c|c|c|}
\hline & \multicolumn{3}{|c|}{ Root fresh weight (g) } & \multicolumn{3}{|c|}{ Root dry weight (g) } & \multicolumn{3}{|c|}{ Disease ratingw $^{w}$} \\
\hline & $\mathbf{P C}^{\mathbf{x}, \mathbf{y}}$ & $75 \%$ & $50 \%$ & PC & $75 \%$ & $\mathbf{5 0 \%}$ & PC & $75 \%$ & $50 \%$ \\
\hline Control $^{\mathrm{z}}$ & $321.06 \mathrm{~A} \mathrm{a}$ & $199.82 \mathrm{~A} \mathrm{~b}$ & $139.09 \mathrm{~A} \mathrm{c}$ & $60.07 \mathrm{~A} \mathrm{a}$ & $40.82 \mathrm{~A} \mathrm{~b}$ & $29.50 \mathrm{~A} \mathrm{c}$ & $0.20 \mathrm{~B} \mathrm{a}$ & $0.70 \mathrm{~A} \mathrm{a}$ & $0.50 \mathrm{~A} \mathrm{a}$ \\
\hline BSBMV & $280.58 \mathrm{~A} \mathrm{a}$ & $201.34 \mathrm{~A} \mathrm{ab}$ & $119.96 \mathrm{~A} \mathrm{~b}$ & $46.90 \mathrm{AB} a$ & $42.54 \mathrm{~A} \mathrm{ab}$ & $24.72 \mathrm{~A} \mathrm{~b}$ & $1.40 \mathrm{~A} \mathrm{a}$ & $0.60 \mathrm{~A} \mathrm{a}$ & $0.90 \mathrm{~A} \mathrm{a}$ \\
\hline $\begin{array}{c}\text { BSBMV+ } \\
\text { BNYVV }\end{array}$ & $211.22 \mathrm{~B} \mathrm{a}$ & $200.28 \mathrm{~A} \mathrm{ab}$ & $118.21 \mathrm{~A} \mathrm{~b}$ & $39.12 \mathrm{AB}$ a & $34.30 \mathrm{~A} \mathrm{a}$ & $23.90 \mathrm{~A} \mathrm{~b}$ & $1.70 \mathrm{~A} \mathrm{a}$ & $0.90 \mathrm{~A} \mathrm{~b}$ & $1.00 \mathrm{~A} \mathrm{~b}$ \\
\hline BNYVV & $213.60 \mathrm{~B} \mathrm{a}$ & $175.68 \mathrm{~A} \mathrm{a}$ & $98.46 \mathrm{~A} \mathrm{~b}$ & $32.08 \mathrm{~B} \mathrm{a}$ & $32.80 \mathrm{~A} \mathrm{a}$ & $18.88 \mathrm{~A} \mathrm{~b}$ & $2.35 \mathrm{~A} \mathrm{a}$ & $0.50 \mathrm{~A} \mathrm{~b}$ & $1.00 \mathrm{~A} \mathrm{~b}$ \\
\hline
\end{tabular}

${ }^{\mathrm{w}}$ On a scale of 0 to 4 , where 0 represented a healthy beet and 4 a small, hairy, and stunted or rotted beet.

${ }^{x} \mathrm{PC}, 75 \%$, and $50 \%$ represent pots irrigated at pot capacity, $75 \%$ pot capacity, and $50 \%$ pot capacity, respectively.

${ }^{y}$ Means followed by the same uppercase letter within a column are not significantly different by Duncan's multiple range test $(P=0.05)$. Means followed by the same lowercase letter within a row are not significantly different by Duncan's multiple range test $(P=0.05)$.

${ }^{\mathrm{z}}$ Sugar beet seed were either noninoculated or inoculated with Polymyxa betae spores infected with Beet necrotic yellow vein virus (BNYVV), Beet soilborne mosaic virus (BSBMV), or BNYVV+BSBMV. 
plots caused an increase in disease development compared with less irrigated plots. They concluded that in Phytophthora-infested fields, a well-timed, less frequent irrigation of shorter duration would increase yield. In our study, a 4-week irrigation treatment achieved the highest yield by minimizing disease while applying adequate water for root growth.

Although we did not find any significant interaction between the virus used and the irrigation frequency in our field study, we found significant differences in yield, percent sugar, and disease index between the two viruses. BNYVV consistently reduced yield and percent sucrose regardless of the irrigation treatment. On the other hand, yield from beets inoculated with BSBMV was not affected by the pathogen and was not significantly different from the control treatment. Phenotypically at harvest, taproots infected with BSBMV showed symptoms such as a greater growth of lateral hairy roots and some constriction similar to the sugar beets inoculated with BNYVV. However, these symptoms were not as severe as those from beets inoculated with BNYVV, and disease ratings for both years of the study were consistently lower than for the BNYVV treatment. Furthermore, in the 1997 growing season, disease ratings for the BSBMV treatment were not significantly different than for the noninoculated treatment. This is in agree- ment with field observation described by Heidel et al. (10). Beets infected with a combination of BNYVV+BSBMV had a consistently higher root yield and percent sucrose than beets inoculated with BNYVV, and disease severity was also lower than the BNYVV treatment in both years of the study. These results indicate a possible biocontrol of BNYVV by BSBMV through cross protection (13).

The results from the greenhouse study are in agreement with those obtained from the field experiment, except for results obtained from the first harvest, in which the only significant effect was the irrigation treatment. As expected, beets in treatments with less irrigation had lower leaf area, shoot dry weight, and root fresh and dry weight. This was probably due to the artificial growth environment and absence of the severe stress conditions to which plants in the field are typically exposed.

Effects of inoculation treatments were significant for root fresh and dry weight and disease rating at the second harvest. A significant irrigation by inoculation interaction also was found for the same variables. Reducing irrigation was effective in reducing disease and improving yield. Significant differences were found for all yield components when the pots were kept at full water holding capacity. Beets in the BNYVV treatment had significantly lower root fresh weight than those in the control

Table 7. Effect of irrigation and inoculation treatments on total plant evapotranspiration for the greenhouse experiment

\begin{tabular}{lccc}
\hline & \multicolumn{3}{c}{ Total seasonal plant evapotranspiration (g of water) } \\
\cline { 2 - 4 } Inoculation $^{\mathbf{x}}$ & $\mathbf{P C}^{\mathbf{y}}$ & $\mathbf{7 5 \%}$ & $\mathbf{5 0 \%}$ \\
\hline Control & $28,479 \mathrm{a}^{\mathrm{z}}$ & $20,017 \mathrm{a}$ & $11,722 \mathrm{a}$ \\
BNYVV+BSBMV & $26,206 \mathrm{~b}$ & $21,395 \mathrm{a}$ & $9,790 \mathrm{a}$ \\
BSBMV & $26,920 \mathrm{~b}$ & $20,544 \mathrm{a}$ & $9,249 \mathrm{a}$ \\
BNYVV & $24,532 \mathrm{c}$ & $20,440 \mathrm{a}$ & $11,132 \mathrm{a}$ \\
\hline
\end{tabular}

${ }^{\mathrm{x}}$ Sugar beet seed were either noninoculated or inoculated with Polymyxa betae spores infected with Beet necrotic yellow vein virus (BNYVV), Beet soilborne mosaic virus (BSBMV), or BNYVV+BSBMV.

y $\mathrm{PC}, 75 \%$, and $50 \%$ represent pots irrigated at pot capacity, $75 \%$ pot capacity, and $50 \%$ pot capacity, respectively.

${ }^{\mathrm{z}}$ Means followed by the same letter within a column are not significantly different by Duncan's multiple range test $(P=0.05)$.

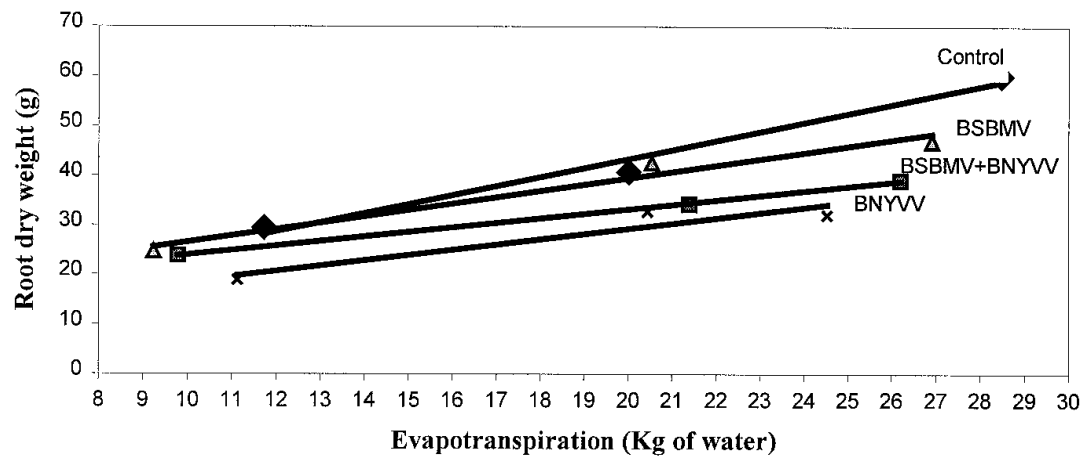

Fig. 2. Relationship between evapotranspiration and dry root weight of greenhouse grown sugar beets inoculated with Polymyxa betae spores infected with Beet necrotic yellow vein virus (BNYVV), Beet soilborne mosaic virus (BSBMV), BNYVV+BSBMV, or noninoculated.

and BSBMV treatments. However, when soil moisture was reduced to $75 \%$ of pot capacity, the differences among all the inoculation treatments became nonsignificant. Furthermore, a significant reduction in root dry weight (50\% reduction) occurred at pot capacity from the noninoculated treatment to the BNYVV treatment. No significant weight reduction was found among all treatments at $75 \%$ pot capacity. The weight loss due to the reduced irrigation level was about $30 \%$ compared with a weight loss close to $50 \%$ due to the virus infection.

Differences in disease rating in the greenhouse study were not as striking as those from the field experiment. This, once again, was likely due to the artificial environment in which the sugar beets were grown. The pot environment seemed to be more conducive to a greater proliferation of lateral roots making it more difficult to rate the beets within the various inoculation treatments. However, irrigation was effective in reducing disease severity. Disease expression in beets inoculated with BNYVV was completely controlled by reducing soil moisture to $75 \%$ of the pot capacity. A significant reduction in disease severity also was observed in the BNYVV+BSBMV treatment when soil moisture was reduced to $75 \%$ of pot capacity. These results are supported by those obtained by Rush and Vaughn (16). They found a positive correlation between incidence of Aphanomyces-caused seedling disease and soil matric potential. Seedlings in pots irrigated only at preplanting had significantly lower disease ratings than pots irrigated for emergence after planting. The authors attributed lower disease incidence to soil matric potential that was too low for zoospores to freely move but high enough for seed to germinate and produce seedlings.

In conclusion, irrigation management is a key to obtaining profitable sugar beet yields in the presence of certain soilborne pathogens. Growers should pay close attention to irrigation scheduling and apply the amount of water necessary to produce good quality sugar beets without losing yield to pathogens. Furthermore, in areas where groundwater is the only available water resource, net return should be calculated considering the short-term return from saving energy necessary to pump water from wells and the long-term return of preserving the aquifer.

\section{LITERATURE CITED}

1. Baker, J. M., Wraith, J. M., and Dalton, F. N. 1992. Root function in water transport. Pages 53-72 in: Advances in Soil Science, 19. Springer-Verlag, New York.

2. Biles, C. L., Lindsey, D. L., and Liddell, C. M. 1992. Control of Phytophthora root rot of chile peppers by irrigation practices and fungicides. Crop Prot. 11:225.

3. Campbell, W. A., and Copeland, O. L. 1954. Little leaf disease of shortleaf and loblolly pines. U.S. Dep. Agric. Circ. 940. 
4. Camprag, D. 1976. The effect of irrigation on the occurrence of some important sugar beet pests in Yugoslavia and other country of southeastern Europe. Pages 449-457 in: Proc. Winter Congr. Int. Inst. Sugar Beet Res., 39th.

5. Cappaert, M. R., Powelson, M. L., Christensen, N. W., and Crowe, F. J. 1992. Influence of irrigation on severity of potato early dying and tuber yield. Phytopathology 82:1448-1453.

6. Cappaert, M. R., Powelson, M. L., Christensen, N. W., Stevenson, W. R., and Rouse, D. I. 1994. Assessment of irrigation as a method of managing potato early dying. Phytopathology 84:792-800.

7. Duniway, J. M. 1977. Predisposing effect of water stress on the severity of Phytophthora root rot of safflower. Phytopathology 67:884889.

8. Harveson, R. M., and Rush, C. M. 1993. A simple method for field and greenhouse inoculation of Polymyxa betae and beet necrotic yellow vein virus. Phytopathology 83:1216-
1219.

9. Harveson, R. M., and Rush, C. M. 1993. An environmentally controlled experiment to monitor the effect of Aphanomyces root rot and Rhizomania on sugar beet. Phytopathology $83: 1220-1223$.

10. Heidel, G. B., Rush, C. M., Kendall, T. L., Lommel, S. A., French, R. C. 1997. Characteristics of beet soilborne mosaic virus, a furo-like virus infecting sugar beet. Plant Dis. 81:1070-1076.

11. Kramer, P. J. 1980. Plant stress and the origin of adaptations. In: Adaptations of Plants to Water and High Temperature Stress. N. C. Turner and P. J. Kramer, eds. John Wiley \& Sons, New York.

12. Lund, B. M., and Kelman, A. 1977. Determination of the potential for development of bacteria soft rot [Erwinia carotovora] of potatoes. Am. Potato J. 54:211-225.

13. Mahmood, T., and Rush, C. M. 1999. Evidence of cross-protection between beet soilborne mosaic virus and beet necrotic yellow vein virus in sugar beet. Plant Dis. 83:521-
526.

14. Ristaino, J. B., Duniway, J. M., and Marois, J. J. 1988. Influence of frequency and duration of furrow irrigation on the development of Phytophthora root rot and yield in processing tomatoes. Phytopathology 787:1701-1706.

15. Rush, C. M., Piccinni, G., and Harveson, R. M. 1997. Agronomic measures. Pages 243 282 in: Environmentally Safe Approaches to Crop Disease Control. N. A. Rechcigl and J. E. Rechcigl, eds. Lewis Publishers, Boca Raton, FL.

16. Rush, C. M., and Vaughn, K. M. 1993. Effect of irrigation, soil matric potential, and seed priming on sugar beet seed germination and damping-off caused by Aphanomyces cochlioides. Phytopathology 83:202-206.

17. Steel, R. G. D., and Torrie, J. H. 1960. Difference between two regressions. Pages 173-175 in: Principles and Procedures of Statistics. McGraw-Hill, New York.

18. Van Bavel, C. H. M., Lascano, R. J., and Wilson, D. R. 1978. Water relations of fritted clay. Soil Sci. Soc. Am. Proc. 32:317-321. 